\title{
Development of Electronic Module Using Creative Problem-Solving Model Equipped with HOTS Problems on The Kinetic Theory of Gases Material
}

\author{
I Made Astra $^{\text {a) }}$, Raihanati ${ }^{\text {b) }}$, Nur Mujayanah ${ }^{\text {c) }}$ \\ Physics Education Department, Universitas Negeri Jakarta, Jl. Rawamangun Muka No.1, Jakarta \\ 13220, Indonesia

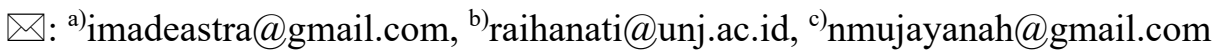

\begin{abstract}
This research aims to develop and produce an e-module of physics using a creative problemsolving model equipped with HOTS problems on the kinetic theory of gases material as independent teaching material for high school students of class XI IPA. The research method used in this study is the Research and Development (R \& D) method using the model of Dick \& Carey. The creative problem-solving model has six learning stages. The electronic module is equipped with HOTS questions, where HOTS is a high- level thinking skill that includes three indicators, including analyzing skills (C4), evaluating (C5), and creating (C6). The instrument used in this study is a questionnaire using a Likert scale. This e-module has gone through a validation test involving material experts, media experts, and learning experts. The results of expert validation are $82.83 \%$. The result in the field-test by physics teachers shows an average score of $83.05 \%$. The field-test results by the students of SMAN 16 Jakarta shows an average score of $93.44 \%$. The result of the effectiveness test had a gain score of 0.502 indicates that the e-module can increase students' high order thinking skills in the middle classification. These results show that the e-module of physics using a creative problem-solving model equipped with HOTS questions in the kinetic theory of gases material can be feasible as independent teaching material and can increase students' high order thinking skills.
\end{abstract}

Keywords: e-module, creative problem solving, HOTS, kinetic theory of gases

\section{INTRODUCTION}

The 2013 curriculum, which applies in Indonesia, is currently improving the learning process will be done in the schools. Based on The Decree of Minister of Education and Culture No. 69/2013, the 2013 curriculum was developed by (1) perfecting teacher-centered learning patterns into learnercentered learning, (2) one-way learning patterns into interactive learning, (3) teaching habits designed into interactive learning, (4) teaching practices developed into active learning look for, (5) the pattern of learning itself into a group learning (team-based), (6) the pattern of learning a single tool into multimedia-based learning, (7) the pattern of mass-based education into the needs of customers (users), (8) the pattern of learning a single science (monodisciplinary) into the learning of plural (multidisciplinary) and (9) passive learning practices into critical education (Muslikh 2013).

The 2013 curriculum adheres to the fundamental view that knowledge cannot be transferred from teacher to student so that changes in learning patterns become student-centered (Keiler 2018). The principle of student-centered learning implies that students occupy a central position as a learning 
subject in the learning process (Tomkin, Beilstein, Morphew, \& Herman 2019). The students are subjects who can search actively, process, construct, and use knowledge. The learning process's success is not measured by the extent to which the subject matter has been delivered by the teacher but by how students have successfully mastered the subject matter. So students are required to play an active role during the learning process (Tomkin, Beilstein, Morphew, \& Herman 2019).

Physics is one of the subjects in science that can develop analytical thinking inductive and deductive in problem-solving related to natural events around. Physics requires understanding rather than memorization but is placed on the understanding and understanding concepts that emphasize the process of knowledge formation through discovery, the presentation of data systematically and based on specific rules, so in learning it needs certain rules (Depdiknas 2003).

According to Hansson, Hansson, Juter, \& Redfors (2020), physics is a fundamental science that is the backbone for developing science and technology. Therefore, learning and understanding physics is primary in learning in schools. However, Turşucu, Spandaw, \& de Vries (2020) said that learning physics in schools tend to get stuck in a routine. The routine in question is the teacher gives formulas, examples of questions, and exercises done by students to get bored quickly. According to Hansson, Hansson, Juter, \& Redfors (2015), physics is challenging to understand because they find many mathematical physics equations, so physics is identified with numbers and formulas.

One of the abstract and microscopic materials of physics is the kinetic theory of gases. The kinetic theory of gases studies related to objects that are not visible, so learning the kinetic gas theory in senior high school becomes challenging to learn without the learning media that can visualize these microscopic objects. Students' difficulty studying the kinetic theory of gases material was also felt by students at SMAN 16 Jakarta. Based on direct observations when teaching skills practice by looking at the original document the re-assessment list of the kinetic theory of gas before remedial in the three classes of XI Science, of the 144 student respondents, only $22 \%$ scored above the minimum completeness criteria. Therefore, the kinetic theory of gas material should be supported with learning media that can help students' understanding and explore the concept of kinetic gas theory and all types of applicable laws. According to Arsyad (2007), learning media includes tools that are physically used to convey teaching material contents. In other words, the media is a component of learning resources or physical vehicles that contain instructional material in the student environment that can stimulate students to learn.

Based on the analysis of the needs of students who are scattered in SMAN 16 Jakarta, currently, $83.33 \%$ of 144 student respondents still use learning media in the form of worksheets, textbooks, and modules in learning physics. As many as $72.22 \%$ of 144 student respondents use teaching material modules as teaching material that is often used in learning physics. However, 95.83\% of 144 student respondents still need other independent teaching materials to support learning to increase their knowledge. This is related to learning that ability is not singular only obtained from the teacher but plural knowledge that can be obtained from anywhere.

In the current learning system, the students are encouraged to empower themselves in learning independently. In the implementation of independent learning, the teacher will provide a module that can be studied and worked at home or school (Wiemer 2019). The module contains learning activities that must be completed. However, the availability of these modules has not been adequate. Moreover, the printed module's use will take more expensive production costs, while paper's durability on the printed module has a limited time. The printed module cannot be equipped with audio or video in its presentation, so it cannot explain the material in more detail.

Along with rapid science and technology, teaching materials are also growing rapidly and easily accessed anywhere. One of the utilization of information and communication technology in education is teaching materials that can be accessed easily on a smartphone. One of the teaching materials is an electronic module, an independent teaching material for students (Muliyati, Bakri, \& Ambarwulan 2018). Changing the pattern of passive learning into active-looking learning makes students required to actively search for material with their efforts and initiatives so that the use of electronic modules can enrich student knowledge. As many as $77.77 \%$ of 144 respondents from SMAN 16 Jakarta were interested in using electronic modules in learning physics, and $68.02 \%$ of 144 student respondents accessed the electronic module quite often on their smartphone. Therefore, the electronic module is an alternative, independent teaching material that can be used by students. 
In the manufacture of electronic modules, the course should contain content appropriate to the students' needs. As many as $100 \%$ of 144 student respondents agreed to need an electronic physics module that includes images, animations, or videos related to everyday life them. Electronic modules with various media content can support learning from single tool learning patterns into multimediabased learning (Bakri, Siahaan, Permana 2016). So that learning activities can be carried out by students in electronic modules to run like real activities, it is also necessary to have a learning model that is relevant to the material so that it can guide the learning process following the demands of the 2013 curriculum. Some learning models that fit the 2013 curriculum are problem-based learning, project-based learning, discovery learning, inquiry learning, and cooperative learning in the problembased learning model divided into various learning models.

One study conducted by Pratiwi (2013) shows that classes taught with creative problem-solving models have critical thinking skills that are higher than the class taught by the teacher's Direct Instruction model at MAN 3 Malang. This is supported by the acquisition of the average value of the two classes. The experimental study has a middle class of 73.41 , while the control class has an intermediate class of 57.23 .

From the research results related to the creative problem-solving model, the model is essential in physics learning on the kinetic theory of gases material that can be collaborated with electronic modules. Moreover, learners that learned with the model have higher critical thinking skills. So that the use of creative problem solving model in the developed electronic modules is expected to make students able to solve various problems related to the material creatively (Meiarti \& Ellianawati 2019). The change in learning patterns from passive to critical also makes learning to have inserted some HOTS (High Order Thinking Skills) items in assessing both in practice exercises, daily assessments, and national examinations.

According to the 2017 High School Development Directorate, presenting HOTS questions in assessment can train students to hone their abilities and skills following the demands of 21st-century competence (Widana 2017). Through examination based on HOTS questions, critical thinking skills (creative thinking and doing), creativity, and self-confidence (learning self-reliance), will be built through training activities to solve various real problems in daily life (problems solving) (Rahmawati, Nisfah, \& Kusairi 2019). Therefore, based on the needs analysis $91.66 \%$ of 144 student respondents needed an electronic module of physics that contained HOTS examples and exercises in it and $91.66 \%$ of the 144 student respondents were interested if there was a electronic module of physics that was equipped with HOTS questions on the kinetic theory of gases material.

Based on the description above, this research intends to develop an electronic module using a creative problem-solving model equipped with HOTS problems on the kinetic theory of gases as independent teaching material for senior high school students of class XI Science.

\section{METHODS}

The research method used is the research and development method. The research and development model used in this research is the Dick \& Carey (2015) model, which has stages:

\section{Identify Instructional Goal(s)}

The initial stage is to determine what it is that students want to do when they complete the instructional program. The identification of objectives was carried out by conducting a needs analysis, literature study, and practical experience during the Teaching Skills Practice course in August November 2018. The analysis of students' needs across SMAN 16 Jakarta shows that currently, 95.83\% of responsive students still need other independent teaching materials to increase their knowledge. Hence, researchers analyze the need to develop different teaching materials in the form of electronic modules. The essential competencies that will be developed in this electronic module material are class XI material in the odd semester KD 3.6. understand the kinetic theory of gases and the characteristics of gases in a closed space. The reason for choosing the material was reflecting on the experience during PKM. Only $22 \%$ of the 144 student respondents achieved KKM completeness before the implementation of remedial, thus indicating that many students had not yet reached the KKM. 


\section{Conduct Instructional Analysis}

The next step is to determine the steps to take so that the learning objectives are achieved. In this step, an analysis of KD 3.6 is carried out to determine indicators of competency achievement. The results of this analysis resulted in 15 indicators of competency attainment in the kinetic theory of gases.

\section{Analyze Learners and Contexts}

In this step, an analysis of the behavior and characteristics of high school students is carried out and an analysis of school conditions. At this stage, the researcher identified and analyzed the characteristics of class XI IPA students at SMAN 16 Jakarta. The results obtained were that most of these students had adequate internet and were accustomed to using computers or laptops and smartphones, indicating that learning using electronic modules as independent teaching materials could be carried out in these schools to increase understanding of concepts and accommodate various levels learning speeds of students. The analysis is also carried out on software that can support the electronic module to be developed. From several available software, iSpring Suite was chosen as the main tool because iSpring Suite is easy to use for non-existent users. Teachers can easily make material and assessments on the electronic module that will be developed.

\section{Write Performance Objectives}

Specific learning objectives come from learning analysis, namely from each Basic Competency developed in SMA class XI Semester I physics material, primarily material the kinetic theory of gases applied in the learning process using electronic modules. Learning objectives suitable for the material of the kinetic theory of gases are translated into 15 learning objectives.

\section{Develop Assessment Instruments}

At this stage, the researcher creates a cognitive assessment grid, analyzes the form of the appropriate questions to meet the achievement of indicators from the kinetic theory of gases. The questions made were pretest and posttest questions. The pretest and posttest items are in the form of an instrument adjusted to the indicators of higher-order thinking skills, including the cognitive domains $\mathrm{C} 4$ - C6 in the revised bloom taxonomy, according to the clear indicators related to higher-order thinking skills. Furthermore, the researchers made instrument grid items for validation tests by material experts, media experts, and learning experts gave to physics education lecturers as validators. After that, the researchers made a field trial instrument, which was given to physics teachers and students at SMAN 16 Jakarta. Researchers made validation test instrument items and field trials to determine the electronic module's feasibility level for the developed gas kinetic theory material.

\section{Develop Instructional Strategy}

Strategies are used to help student development in learning, including pre-learning activities, content presentation, learning activities, active assessment, and follow-up activities related to newly learned abilities. Each learning activity will be arranged based on the stages in the Creative Problem Solving model. Based on OFSIDA criteria for the Osborn-Parnes model, namely the stages of Objective Finding, Fact Finding, Problem Finding, Idea Finding, Solution Finding, and Acceptance Finding (Sousa, Monteiro, Walton, \& Pissarra 2013). Furthermore, the researchers arranged the components of the electronic modules and designed the electronic modules. Then prepare the contents of the electronic module. The electronic module developed on the Kinetic Gas Theory material using the Creative Problem Solving model will be divided into three learning activities. The contents of the electronic module learning materials are equipped with pictures/graphics, audio, video, animation, and experiments according to the contents of the electronic module. 


\section{Develop and Select Instructional Materials}

The next step is to produce learning materials that are following the learning strategy. Learning materials consist of guides for students, learning materials, and assessments. Researchers combine learning materials into electronic modules in the iSpring Suite 9 Software. First, compile learning materials in the Timeline contained in the Interactions panel enriched with images/graphics, audio, animation, and learning videos made in each software. As for independent exercises, learning activities are made in the Graded Quiz, which is on the Quizzes panel which is enriched with various types of questions such as True / False, Multiple Choice, and others.

Furthermore, the researcher uploaded other supporting materials and teaching materials that had been incorporated in iSpring Suite 9.7 into 64-bit Microsoft Powerpoint, which was then stored using HTML format. The final arrangement is to make a multiple-choice test kit and a description that students must answer with a deadline at the end of the lesson. The test sets made are 15 questions in two hours of lessons with one chance. The test will be completed with HOTS questions.

\section{Design and Conduct Formative Evaluation of Instruction}

After the electronic module is complete, the next step is to consult the product with the supervisor. This stage is carried out to determine the product's feasibility before the due diligence to several validators. After completion, the next step is to validate several physics education study program lecturers as material, learning, and media experts. Validation is carried out to determine the deficiencies of the electronic module made and to find out suggestions for improvement from the lecturers. The tips given are a reference for the researcher's part to improve the independent teaching materials developed. If a series of validations or due diligence has been carried out, the product can be tried out in schools. The school used is SMAN 16 Jakarta. The class used for field trials is class XII IPA. Students selected in the field trial amounted to 30 people.

\section{Revise Instruction}

The next step is to revise the product. Data from the formative evaluation is useful for identifying product deficiencies and then used to improve product quality. The final step in research on the electronic physics module development is to revise the electronic physics module device based on expert advice on the feasibility test. Then, after a field trial was carried out on class XII IPA students, the electronic module product was suitable for use at SMAN 16 Jakarta.

The preliminary research for needs analysis is done through a questionnaire. The questionnaire was addressed to students of class XI Sciences and carried out by distributing written questionnaires. Data on formative evaluations were obtained from the validation test analysis questionnaire and field trials in this research. Material experts conducted validation tests, media experts, and learning experts. In contrast, field trials were conducted on physics teachers at SMAN 16 Jakarta, which were visited one by one. Field trials were conducted on a group of students on a small scale that was gathered in one room then observed the products of the development in the form of an electronic physics module and then filled out a questionnaire provided by the researcher to obtain information from respondents about matters related to the assessment of products that have been developed.

Then to practice higher-order thinking skills (HOTS) within the scope of problem-solving ability is done by using One Group Pre-Test Post-Test that is by giving questions pre-test and post-test to students. Previously, a validity test was conducted by material experts related to the pre-test and posttest questions to be used. The validity test of multiple-choice questions was carried out using the biserial point correlation formula as follows (Arikunto, 2012):

$$
\gamma_{p b i}=\frac{M_{p}-M_{t}}{s_{t}} \sqrt{\frac{P}{Q}}
$$

Information:

$\gamma_{p b i}=$ biserial correlation coefficient 
$M_{p} \quad=$ the mean score of the samples that answered correctly for the questions whose validity was sought

$M_{t} \quad=$ average total score

$S_{t} \quad=$ standard deviation of the total score

$P \quad=$ proportion of samples who answered correctly

$Q \quad=$ proportion of samples who answered incorrectly $(\mathrm{Q}=1-\mathrm{P})$

The calculation results were then consulted with rtable at a significant level of 5\%. If rcount $\gamma_{p b i}$ $>r_{\text {table }}$, then the question is declared valid.

The calculation of question reliability was carried out using the K-R 20 formula (Arikunto, 2012):

$$
r_{11}=\left(\frac{n}{n-1}\right)\left(\frac{s^{2}-\sum P Q}{s^{2}}\right)
$$

Information:

$r_{11}=$ reliability of the question as a whole

$P \quad=$ proportion of samples who answered correctly

$Q \quad=$ proportion of samples who answered incorrectly

$n \quad=$ many questions

$S \quad=$ standard deviation of the problem

The questions' reliability results can then be matched against the reliability coefficient to determine how strong the results obtained.

The gain test $(\mathrm{g})$ is a test carried out to provide an overview of whether students have increased their higher-order thinking skills before and after learning. Calculations based on the results of the pretest and posttest, using the gain test formula according to Hake (1999) are as follows.

$$
\langle g\rangle=\frac{\text { posttest score }- \text { pretest score }}{\text { ideal score }- \text { pretest score }}
$$

The ideal score used in the calculation of this gain test is 100. According to Hake (1999) the results are interpreted according to Table 1. as follows.

TABLE 1. Modified Gain Interpretation (Sundayana, 2014)

\begin{tabular}{cc}
\hline Gain value & Interpretation \\
\hline$-1.00 \leq \mathrm{g} \leq 0.00$ & There was a decline \\
$\mathrm{g}=0.00$ & There was no improvement \\
$0.00<\mathrm{g}<0.30$ & Low \\
$0.30<\mathrm{g}<0.70$ & Middle \\
$0.70<\mathrm{g}<1.00$ & High \\
\hline
\end{tabular}

\section{RESULTS AND DISCUSSION}

The electronic module document for the kinetic theory of gases is divided into three learning activities, namely teaching activities 1 (Law Underlying Ideal Gas), learning activities 2 (Equation of Ideal Gas Circumstances), and activity 3 (Kinetic Theory of Gases and Energy Equipartition). The learning model used in the electronic module is Creative Problem Solving, which consists of the stages of an objective finding, fact-finding, problem finding, idea finding, solution finding, and acceptance finding. The electronic module is created using the Ispring Suite 9 application.

Following is the display of the electronic module according to the syntax of Creative Problem Solving. 


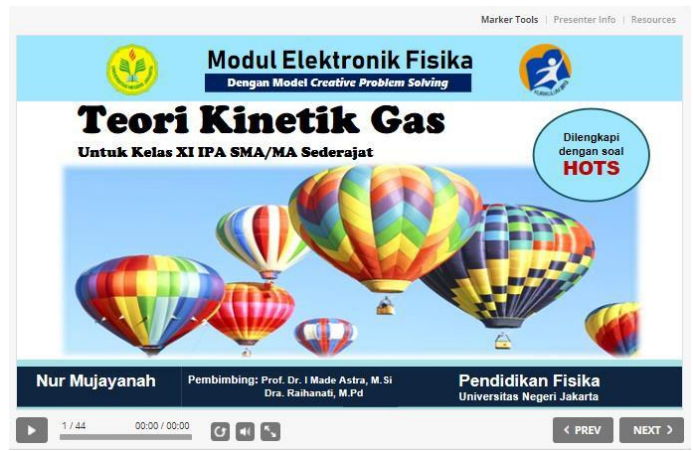

(a)

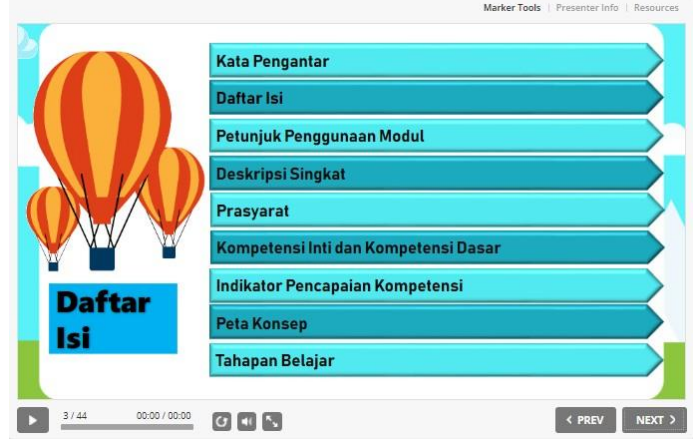

(c)

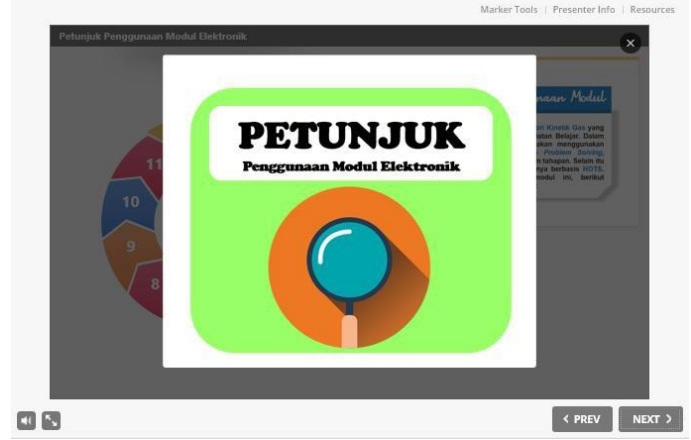

(e)

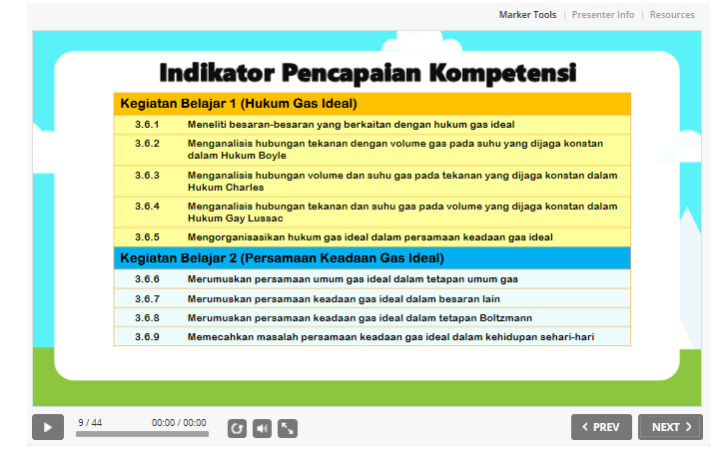

(g)

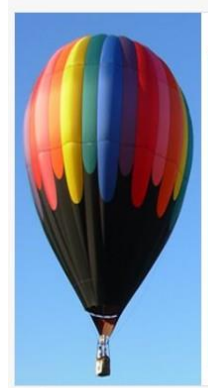

D.

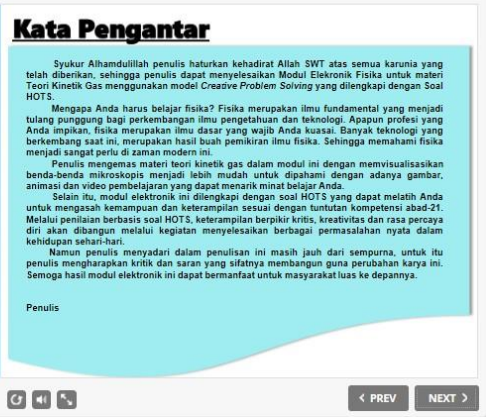

(b)

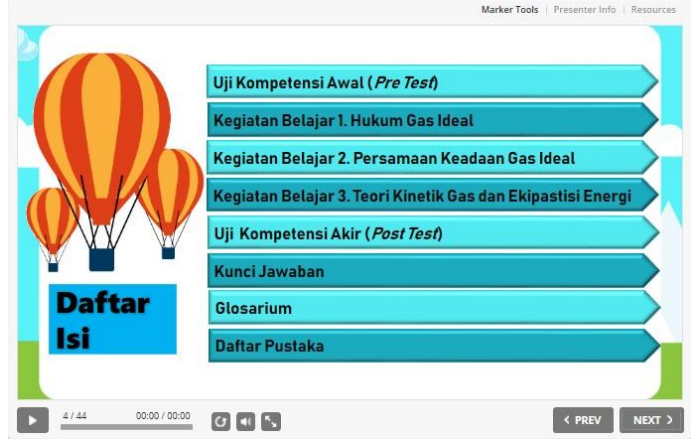

(d)

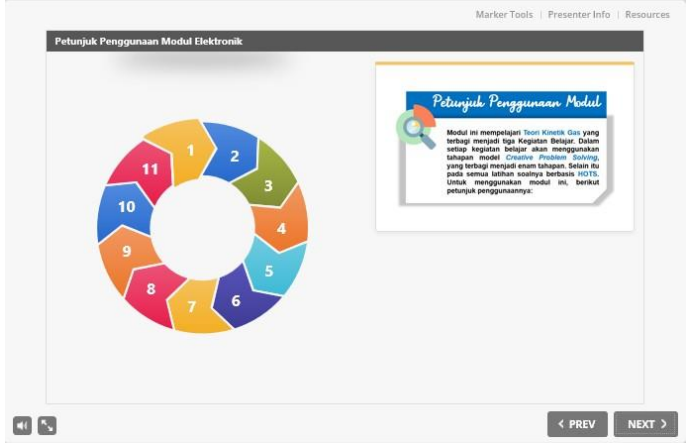

(f)

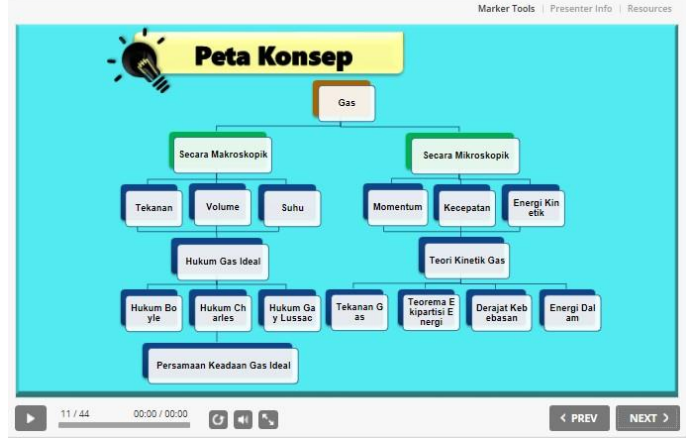

(h) 


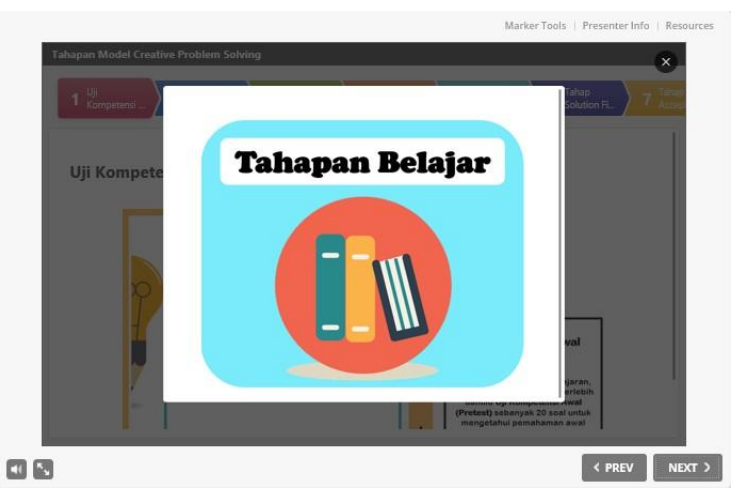

(i)

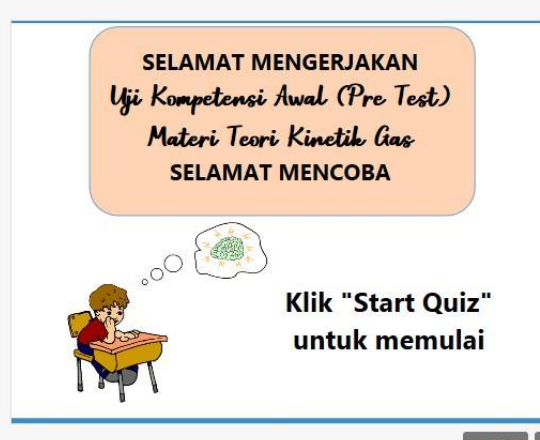

<PRav start Quz >

(k)

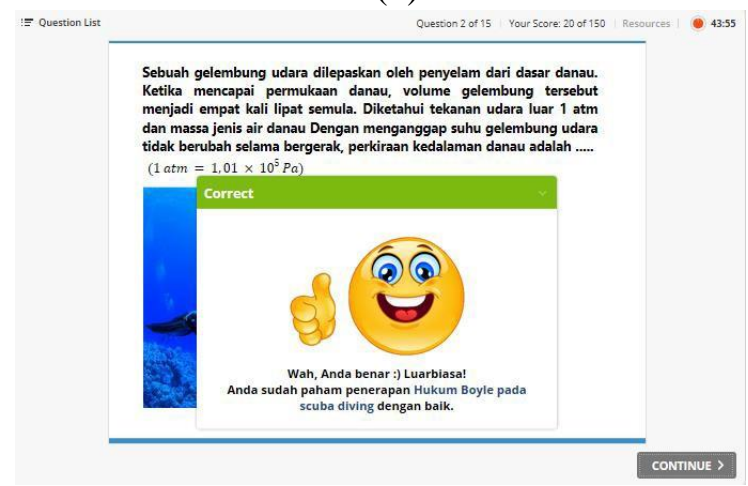

(m)

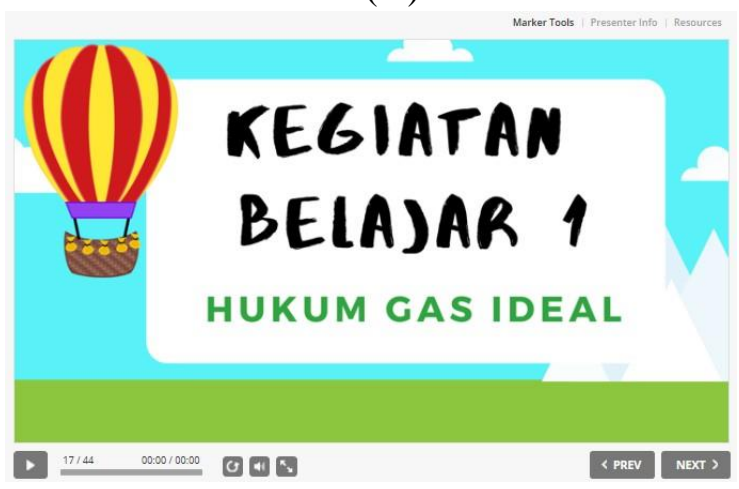

(o)

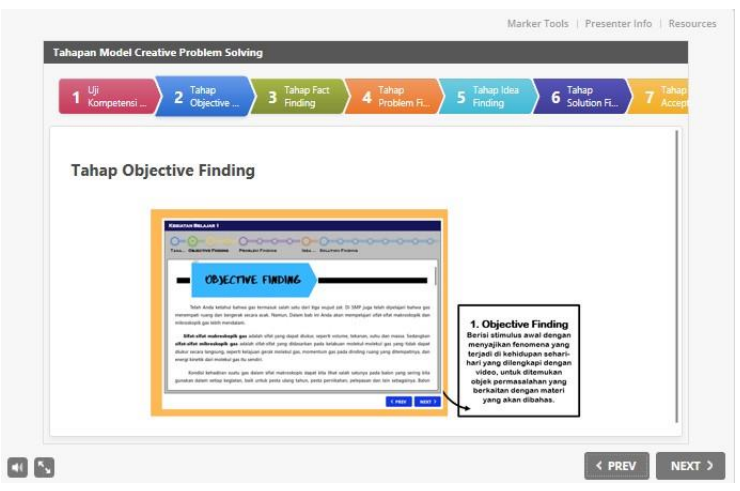

(j)

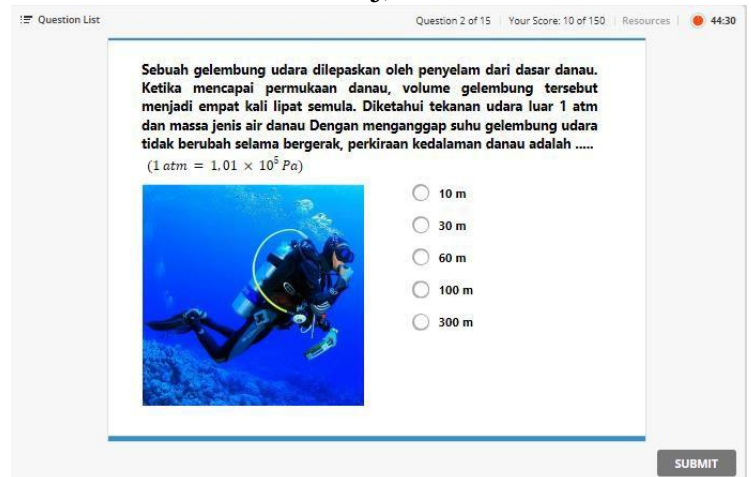

(1)

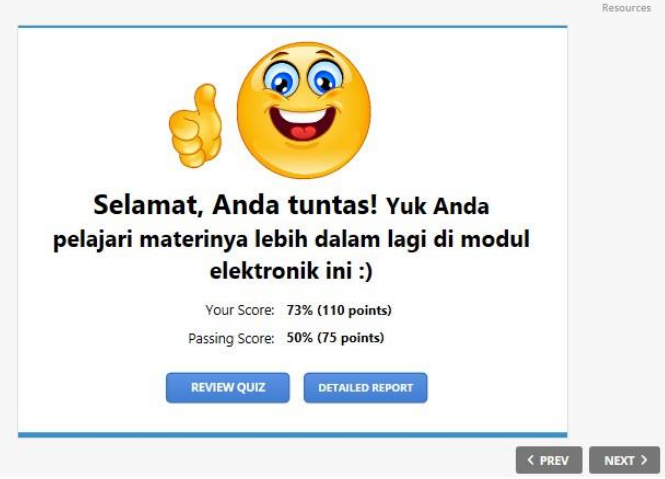

(n)

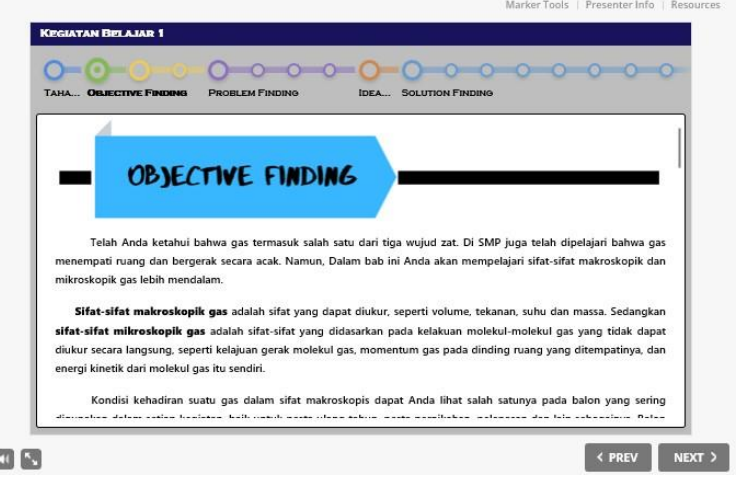

(p) 


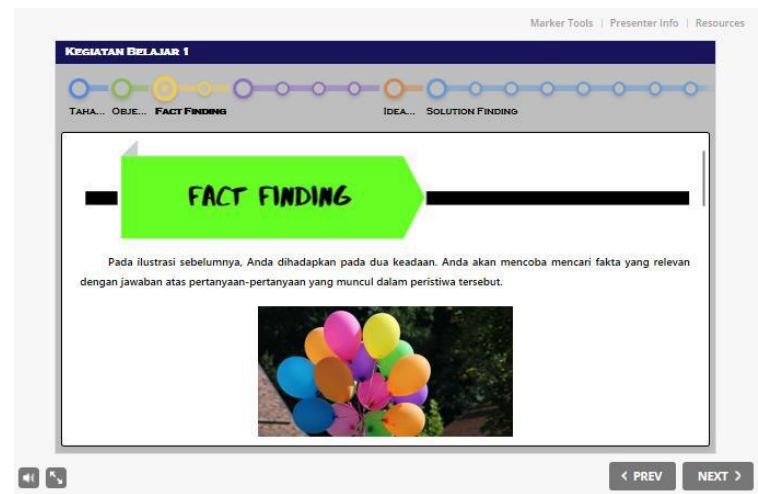

(q)

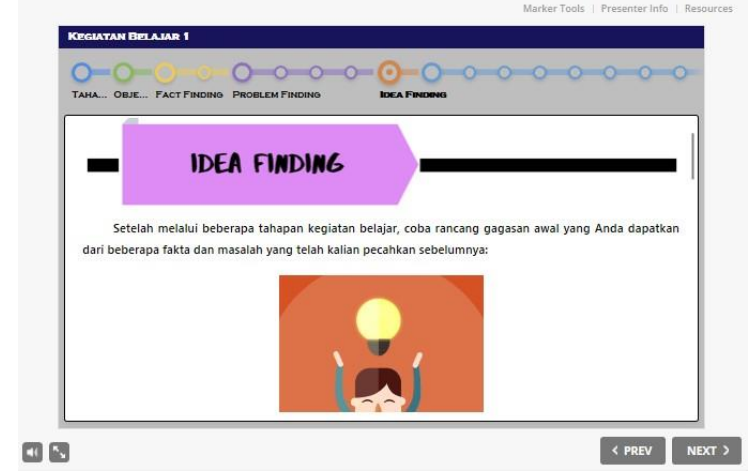

(s)

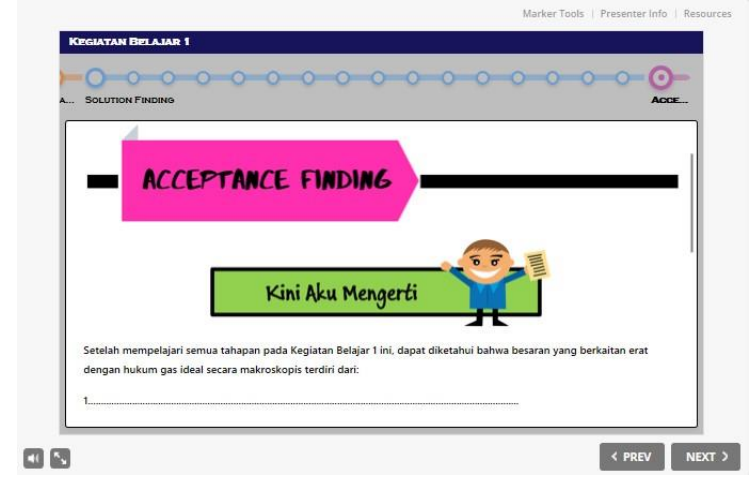

(u)

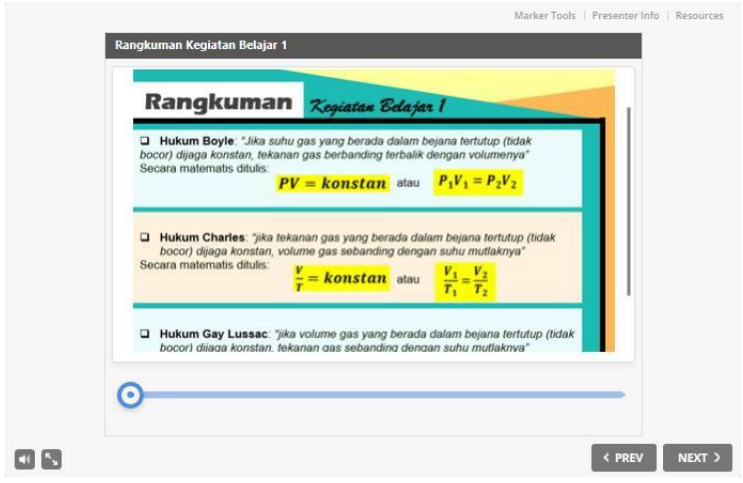

(w)

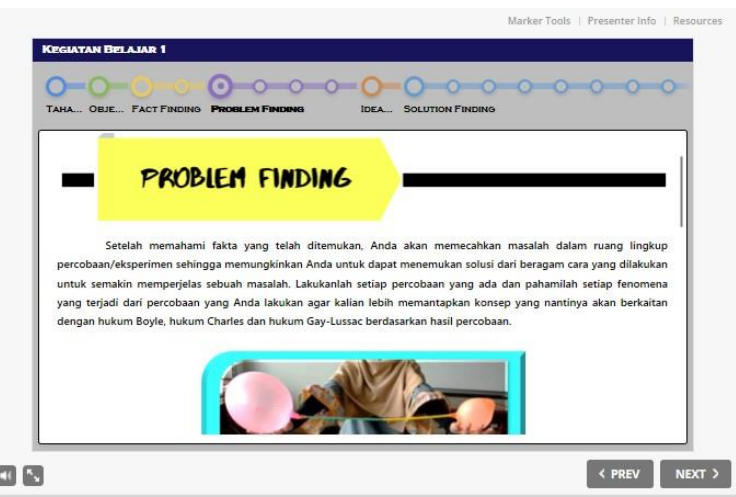

(r)

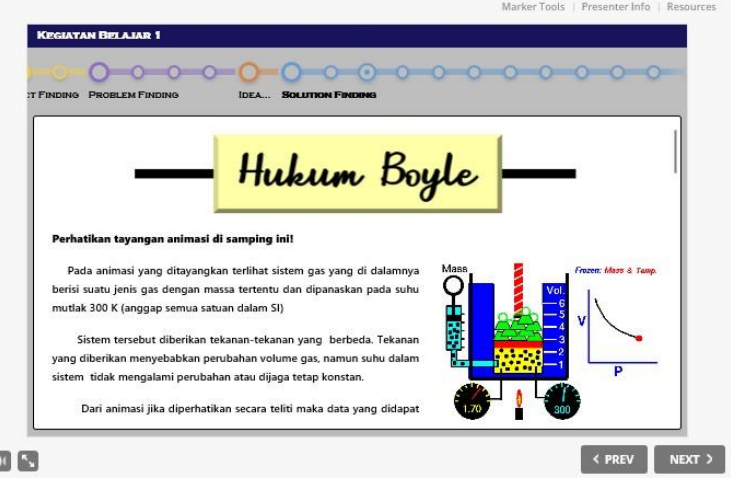

(t)

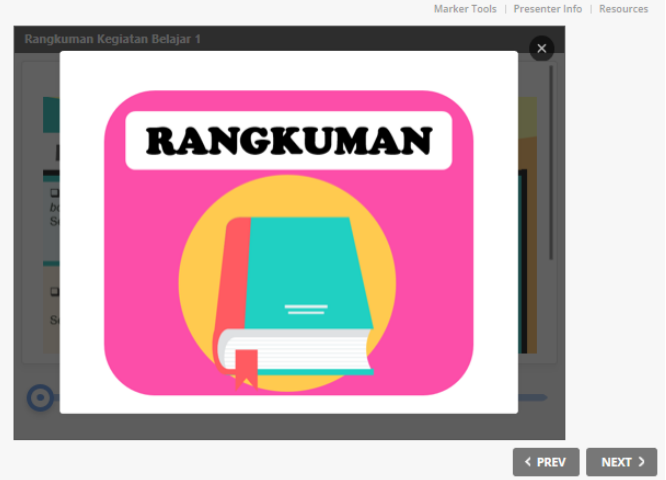

(v)

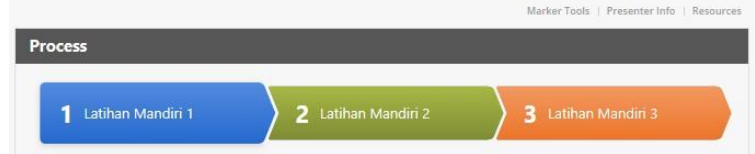

Latihan Mandiri 1

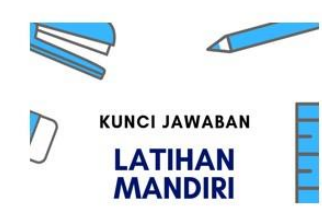

(x) 


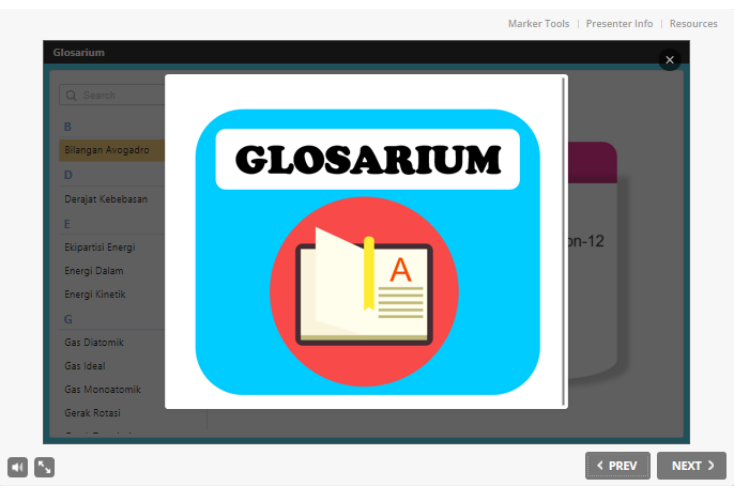

(y)

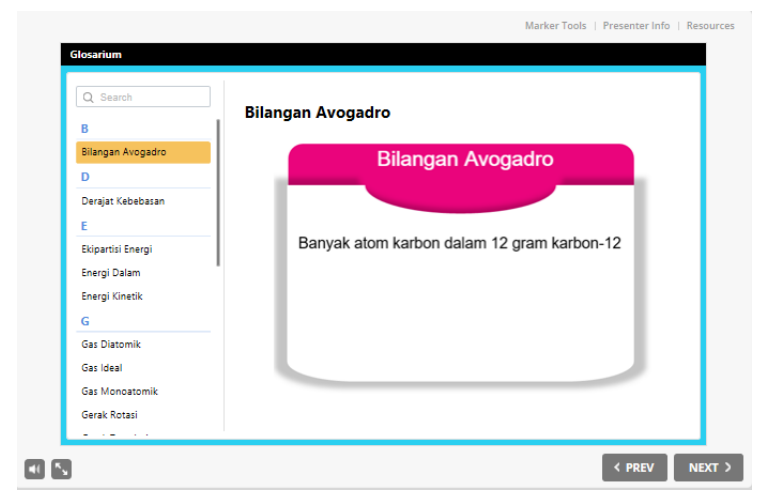

(z)

FIGURE 1. Figure (a) is an electronic module cover display. In the electronic module, there are several components including (b) dan (c) Table of Contents, e) and f) Instructions for using the module, g) indicators, h) concept maps, i) and j)

stages of learning, k), 1), m) and n) Competency Test, o) cover learning activities. Electronic modules are presented

following the Creative Problem-Solving learning stages, namely the "Objective Finding" stage in figure (p), the "Fact-

Finding" stage in the picture (q), the "Problem Finding" stage in the picture (r), the "Idea Finding "in the image (s), the" Solution Finding "stage in the picture $(\mathrm{t})$, the" Acceptance Finding "stage in the picture $(\mathrm{u})$. Finally, the module is equipped with (v) and (w) Summary, (x) Answer key, (y) and (z) Glossary.

The following are the stages of the creative problem solving model in the module.

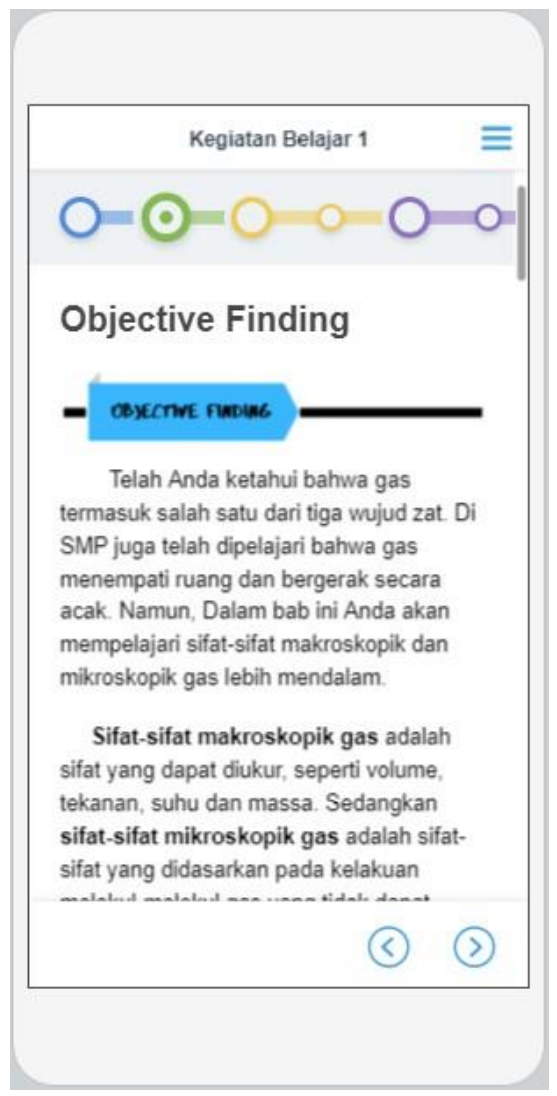

(a)

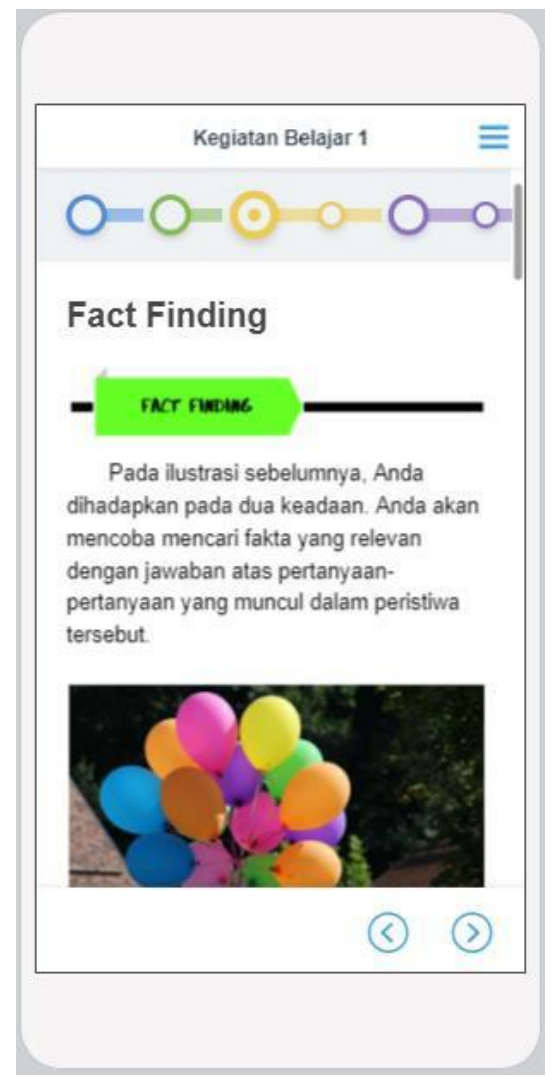

(b) 


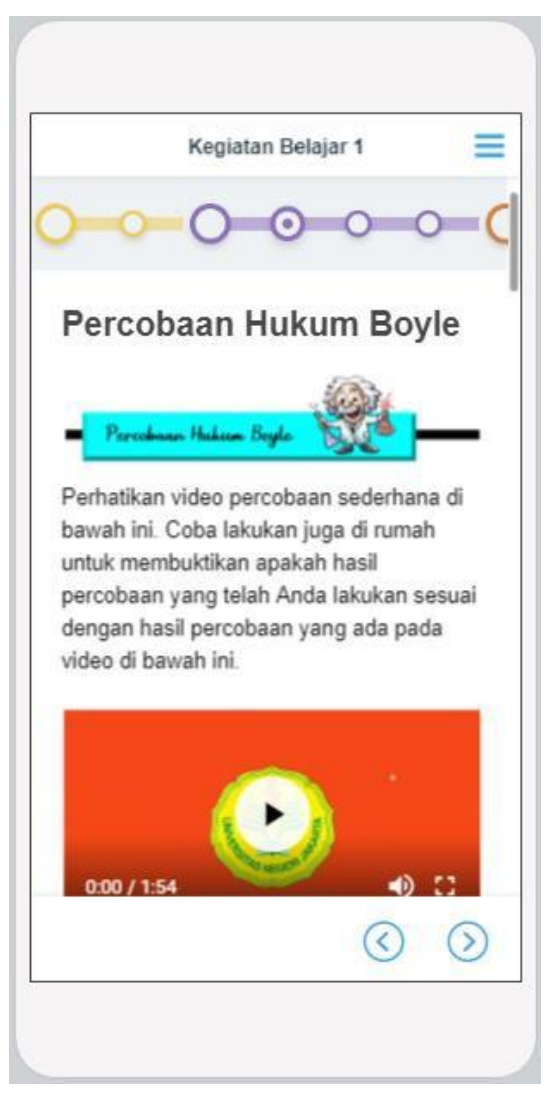

(c)

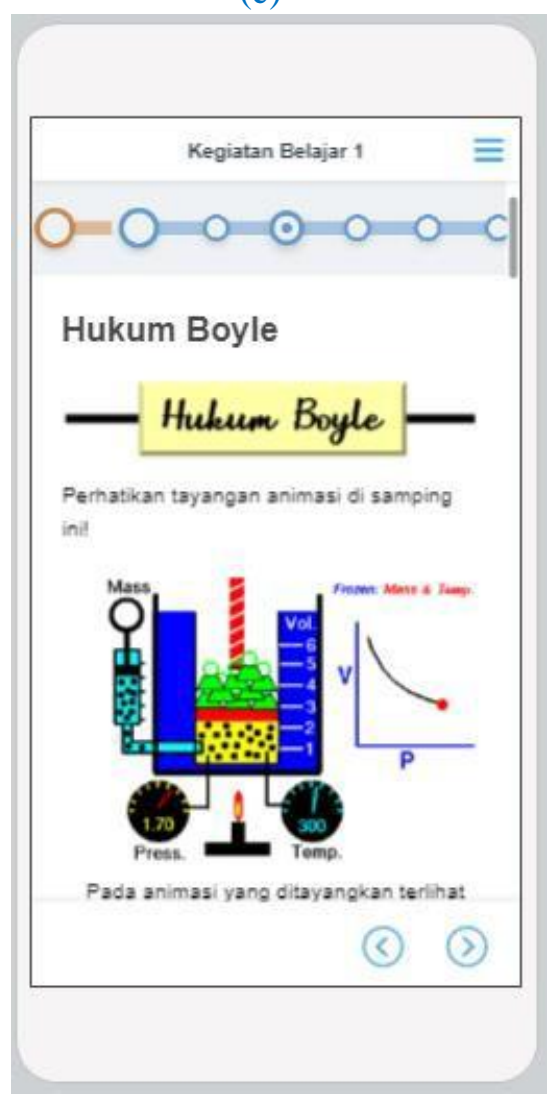

(e)

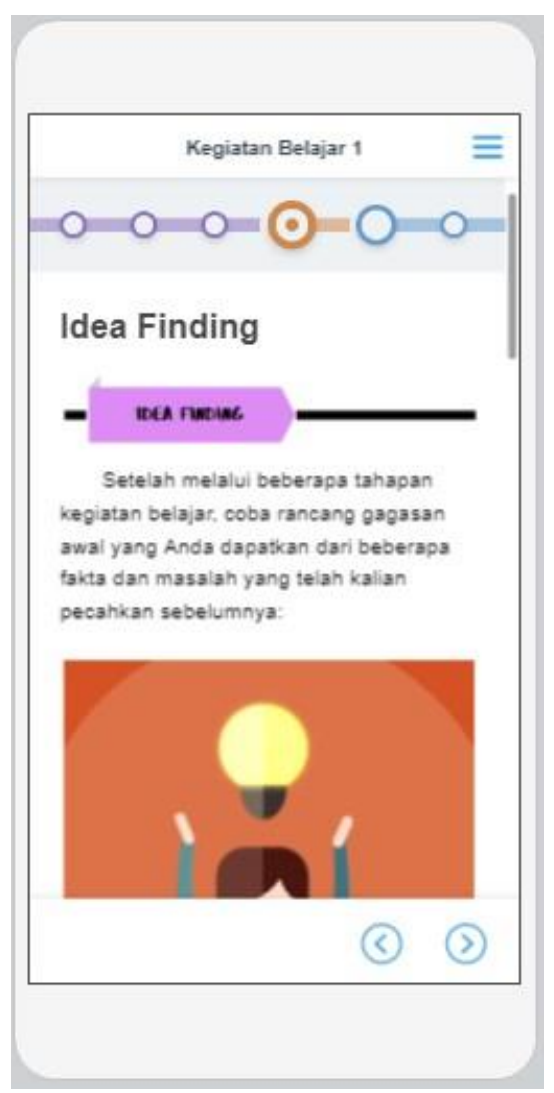

(d)

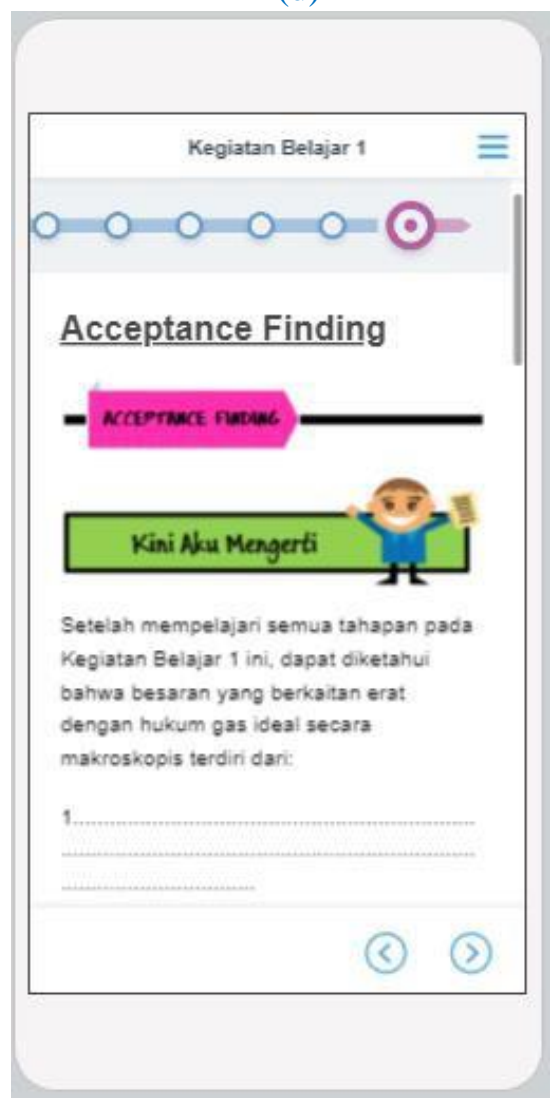

(f)

FIGURE 2. Creative Problem Solving Model Stages (a) Objective Finding stage, (b) Fact Finding stage, (c), Problem Finding stage, (d) Idea Finding stage, (e) Solution Finding stage, (f), Acceptance Finding stage. 
The objective finding stage contains an initial stimulus by presenting the phenomena that occur in everyday life, equipped with videos or pictures, to find the objectives of the problems related to the material to be discussed. Then, the objectives of the problems that have been found are formulated into questions that must be sought for further solutions. Students find relevant facts and solutions to problems based on the objectives found and the issues formulated at the objective finding stage. In the problem-finding stage, there are various ways that students can do to clarify an issue further. For example, by doing simple experiments, demonstrations, or virtual lab labs. So that students are closer to finding solutions. At the idea finding stage, it contains a list of ideas from students to see possible solutions to problem situations. Students will express their ideas in a temporary hypothesis column. Then students will get feedback on which opinions are relevant. The solution finding stage contains criteria that can determine what kind of solution is suitable to solve the problem. In this case, an animation will be displayed, the results of previous scientists' observations, the derivation of formulas, pictures, and graphics to answer the problem's correct solution. Also, examples of questions and practice questions of the HOTS type will be presented in each sub-material. There is also the application of the concept to sub material in everyday life. In the acceptance finding stage, students write the conclusions obtained as a solution to problem-solving. Then students are given practice solving problems related to other real issues related to the material in the form of discussion forums.

The results of the electronic module product validation test by experts produce the following data:

TABLE 2. Product validation test results by media experts

\begin{tabular}{ccc}
\hline Number & Rated Aspect & Interpretation \\
\hline 1 & Electronic module component design & $85.71 \%$ \\
2 & Feasibility electronic module components & $86.11 \%$ \\
3 & Language on electronic modules & $75.00 \%$ \\
\hline
\end{tabular}

TABLE 3. Product validation test results by material experts

\begin{tabular}{ccc}
\hline Number & Rated Aspect & Interpretation \\
\hline 1 & Exposure to the kinetic theory of gases material & $77.50 \%$ \\
2 & The suitability of the e-module components with the material & $85.71 \%$ \\
3 & The suitability of HOTS items with material & $75.00 \%$ \\
4 & Language on the kinetic theory of gases & $81.25 \%$ \\
\hline
\end{tabular}

TABLE 4. Product validation test results by learning experts

\begin{tabular}{ccc}
\hline Number & Rated Aspect & Interpretation \\
\hline 1 & Characteristics of learning with models & $87.50 \%$ \\
2 & Feasibility analysis of learning content & $85.71 \%$ \\
3 & The suitability of the learning design & $88.89 \%$ \\
4 & Language on learning & $83.33 \%$ \\
\hline
\end{tabular}

Formative evaluation results above obtained an average value of $82.83 \%$, so it can be said that the electronic module of the kinetic theory of gases using the creative problem-solving model is feasible to use.

Furthermore, the electronic module field trials results by physics teachers and students produce the following data.

TABLE 5. Results of field trials by physics teacher experts

\begin{tabular}{ccc}
\hline Number & Rated Aspect & Interpretation \\
\hline 1 & Scope materials on the kinetic theory of gases & $81.48 \%$ \\
2 & Characteristics of learning with models & $84.52 \%$ \\
3 & Completeness of electronic module components & $84.25 \%$ \\
4 & Language on electronic modules & $81.66 \%$ \\
\hline
\end{tabular}


TABLE 6. Results of field trials by students

\begin{tabular}{ccc}
\hline Number & Rated Aspect & Interpretation \\
\hline 1 & Scope materials on the kinetic theory of gases & $91.33 \%$ \\
2 & Presentation techniques on electronic modules & $95.41 \%$ \\
4 & Language on electronic modules & $93.12 \%$ \\
\hline
\end{tabular}

The results of the field trials above obtained an average value of $83.05 \%$ in field trials by teachers and obtained an average value of $93.44 \%$ in field trials by students so that it can be said that the electronic module of the kinetic theory of gases material uses creative problem-solving model are feasible to use.

Furthermore, to determine the increase in higher-order thinking skills, a field trial was conducted by giving pretest questions before using the product. After the students used the product, a post-test was carried out on 30 students. Pretest questions are the same as post-test questions, but with random numbering and changing numbers on the problems. The questions used for the pretest and post-test were questions that had their validity and reliability tested. Based on the validation of the questions carried out on 40 questions, it was found that 18 questions were declared valid. Furthermore, from the 18 valid questions, a calculation was carried out showing the items' reliability criteria in the "strong" standards. There were 15 questions used to be used as pretest and post-test questions.

Calculating the normalized gain test is to determine the increase in students' value after using the module. The normalized gain tests on the pretest and post-test data obtained the $\mathrm{N}$-Gain value of 0.502 in the "middle" category. The following is the field test result data by students.

TABLE 7. Results Average Value of Pretest, Posttest and Gain

\begin{tabular}{ccc}
\hline Pre-test & Post-test & Gain Value \\
\hline 24.44 & 62.44 & 0.502 \\
\hline
\end{tabular}

Based on the normalized gain test by doing the pretest and posttest, obtaining an average gain of 0.502 , which states that students have increased in higher-order thinking skills in the classification of "middle" improvement.

\section{CONCLUSION}

Based on the experts' validity test, it was $82.83 \%$, the field trial by the physics teacher was $83.05 \%$, the field trial by the students of SMAN 16 Jakarta was $93.44 \%$. The normalized gain test obtained a gain score of 0.502, which shows an increase in students 'high-order thinking skills in the "medium" classification. The electronic module material Kinetic Gas Theory using the Creative Problem Solving model is feasible to use. The use of this electronic module can improve students' higher-order thinking skills.

\section{ACKNOWLEDGMENTS}

Thank you, the author goes to the Physics Education study program, FMIPA, the State University of Jakarta and SMAN 16 Jakarta for helping in carrying out this research.

\section{REFERENCES}

Arikunto, S 2012, 'Dasar-dasar Evaluasi Pendidikan Edisi 2', Jakarta: PT Bumi Aksara.

Arsyad, A 2007, 'Media Pembelajaran', Jakarta: PT. RajaGrafindo Persada.

Bakri, F, Siahaan, BZ, \& Permana, AH 2015, 'Rancangan Website Pembelajaran Terintegrasi dengan Modul Digital Fisika Menggunakan 3D PageFlip Professional', Jurnal Penelitian \& Pengembangan Pendidikan Fisika, vol. 2, no. 2, pp. 113-118. 
Depdiknas 2003, 'Undang-undang RI Nomor 20 Tahun 2003 Tentang Sistem Pendidikan Nasional,

Dick, W, \& Carey, L 2015, 'The Systematic Design of Instructional', New Jersey: Pearson Education.

Hake, RR 1999, 'Analyzing Change/Gain Scores', AERA-D, American Educational Research Association's Division D, Measurement and Reasearch Methodology.

Hansson, L, Hansson, Ö, Juter, K, \& Redfors, A 2015, 'Reality-Theoretical Models-Mathematics: A Ternary Perspective on Physics Lessons in Upper-Secondary School' Sci \& Educ, vol. 24, pp. 615644.

Hansson, L, Hansson, Ö, Juter, K, \& Redfors, A 2020, 'Curriculum Emphases, Mathematics and Teaching Practices: Swedish Upper-Secondary Physics Teachers' Views', Int J of Sci and Math Educ.

Keiler, LS 2018, 'Teachers' roles and identities in student-centered classrooms', International Journal of STEM Education, vol. 5, Article number: 34.

Meiarti, D \& Ellianawati, E 2019, 'Mind Mapping Based Creative Problem Solving: Train The Creative Thinking Skills of Vocational School Students in Physics Learning', Jurnal Penelitian \& Pengembangan Pendidikan Fisika, vol. 5, no. 2, pp. 91-100.

Muliyati, D, Bakri, F, \& Ambarwulan, D 2018, 'Aplikasi Android Modul Digital Fisika Berbasis Discovery Learning', Jurnal Wahana Pendidikan Fisika, vol. 3, no.1, pp. 74-79.

Muslikh 2013, Peraturan Menteri Pendidikan Pendidikan dan Kebudayaan Republik Indonesia Nomor 69 Tahun 2013 Tentang Kerangka Dasar dan Struktur Kurikulum Sekolah Menengah Atas/Madrasah Aliyah, Jakarta: Kemdikbud.

Pratiwi, WT 2013, 'Pengaruh Penerapan Creative Problem Solving (CPS) Terhadap Kemampuan Berpikir Kritis Siswa pada Mata Pelajaran Fisika Kelas XI IPA MAN 3 Malang’, sl, sn.

Rahmawati, A, Nisfah, NL, Kusairi, S 2019, 'The Capability Analysis of High Order Thinking Skills (HOTS) on Dynamic Electricity Material in Junior High School', Jurnal Penelitian \& Pengembangan Pendidikan Fisika, vol. 5, no. 2, pp. 163-168.

Sousa, F, Monteiro, I, Walton, A, \& Pissarra, J 2013, '.Learning from Failure: A Case Study on Creative Problem Solving', Procedia - Social and Behavioral Sciences, vol. 75, pp. 570-580.

Sundayana, R 2014, 'Statistika Penelitian Pendidikan', Bandung: Alfabeta.

Tomkin, JH, Beilstein, SO, Morphew, JW, \& Herman, GL 2019, 'Evidence that communities of practice are associated with active learning in large STEM lectures', International Journal of STEM Education, vol. 6, article number: 1.

Turşucu, S, Spandaw, J, \& de Vries, MJ 2020, 'Search for Symbol Sense Behavior: Students in Upper Secondary Education Solving Algebraic Physics Problems', Res Sci Educ, vol. 50.

Widana, IW 2017, 'Modul Penyusunan Soal HOTS', Jakarta: Kementerian Pendidikan dan Kebudayaan.

Wiemer M 2019, 'Learning through Research: Independent Learning. Self-Learning Processes and Self-Learning Abilities in Inquiry-Based Learning', Inquiry-Based Learning - Undergraduate Research, pp. 29-36. 